\title{
Erfahrungsbericht
}

\author{
Elisabeth Ansen Zeder*
}

\section{Is a philosophically-oriented discussion serving the purpose of spiritual care?}

DOI 10.1515/spircare-2016-0165

New philosophical practices (NPP) are developing in schools from preschool to secondary level, as well as in health care settings. A classroom community of inquiry is a group of children who inquire together about common problematic issues in such a way that they build on each other's ideas, offer each other counterexamples, question each other's inferences and encourage each other to come up with alternative views and solutions to the problem at hand and follow the inquiry where it leads. Those new practices rely on a philosophically-oriented discussion or community philosophy. Therapists like Cinq-Mars (2005) or Loison-Apter $(2010,2011)$ observe that beneficial therapeutic effects follow philosophical activity according to current practice in community philosophy (CP). LoisonApter (2010, 2011) speaks about the psychotherapeutic effects of using philosophy through philosophical dialogue as practiced in thinking communities according to the method developed by Lipman $(1995,2006)$. She finds a correlation between the psychotherapeutic effects and the quality of the relational climate of the thinking community, linked at last with the quality of learning how to philosophize.

The child psychiatrist Ribalet (2008) offered a philosophical workshop to prevent mental suffering. Like the ancient sages, he acknowledged the therapeutic virtue of philosophy because it "takes care of the soul". This therapeutic virtue lies in the fact that the philosophical workshop aims at developing the capability to reflect, caring for others, and thus self-esteem. In doing so, he endorses an existential therapeutic approach which is less known in French speaking countries since Viktor Frankl's “Man's Search for Meaning: An Introduction to Logotherapy” has only been translated in 1988, while already published in German in 1946 and in English in 1959.

We think therefore that the new philosophical practices could help question the meaning, not the global meaning, but the meaning a person is giving to his life's

*Korrespondenzautor: Elisabeth Ansen Zeder, Fribourg,

E-Mail: zederE@edufr.ch journey at a given time. The existential analysis or logotherapy developed by Frankl is defined as "a therapy based on the meaning of life" (Frankl 2006: 99). This author speaks also about "noogenic neurosis" as the impossibility to find meaning in life due to an existential vacuum. For Frankl "the noogenic neuroses result from a lack of meaning in life” (Frankl 2006: 101).

While the $21^{\text {st }}$ century might seem to be much "psychologized", we agree with Frankl (2006) that it is not possible to leave aside existential questions which are linked to the transcendental or noetic dimension of our humanity, as it is an integral part of it.

Furthermore, Besson (2014), a pioneer known for integrating spiritual issues in mental health care at the CHUV (Hospital of Lausanne), points out in an interview broadcasted by “A vue d'Esprit" in February 2014, that there is a relevant link to be seen between mental health and spirituality when defining mental-health policy as part of a community intelligence seeking answers in the prevention of and caring for people suffering from mental distress.

The positive psychology of Seligman (Seligman 1992; Seligman and Peterson 2004 in Peterson \& Park 2011), and also Pesseschkian (2009) invites us to build up the energies which allow human beings to exercise their self-effectiveness, to manage their emotions and cognitions, and to identify talents in order to maximize their personal development and learning skills when facing their suffering.

Could the new philosophical practices be involved in that dynamic?

This question has led us to put into place philosophically-oriented discussion groups at a small institution in Western Switzerland, Bethel House, which is a transitional venue for adults who suffer temporarily from a mental vulnerability.

\section{The context of the research}

Bethel House is a young institution founded in 2010. It is part of the Canton of Vaux Association of Socio-medical Establishments [AVDEMS] and the Riviera and the Pays- 
d'en-Haut Association of Coordinated Care [ASCOR]. It is an innovation in the landscape of mental health in Western Switzerland.

This exploratory research started in May 2013, thanks to a collaboration with Dr Gaillard-Wasser (2013), psychiatrist and psychotherapist (affiliated with the Swiss Medical Association FMH) who was in charge of Bethel House from its inception in 2010 until the end of 2015.

From March 2014 until mid-April 2014 we introduced 4 modules of 2 sessions each in the context of an existing workshop called: "Speaking while using a topic."

The experience involves 14 adults who are experiencing psychological distress and who were staying at Bethel House during the dates proposed.

The hosting context of the venue is a short-term offer limited to a month. We choose to discuss using a popular tale or a myth as found in Piquemale's book on "Philofables" (Piquemal 2013).

We have asked each participant to sign a participation agreement to this research project. Each session has been recorded and then put in writing.

The chaplain of the institution has participated to the meetings.

\section{Methodological framework of the project}

The two-session module and four phases will respect a formal and ritualized arrangement, as described by Hess (2013) and Gagnon (2011).

The discussion groups are made of at least 3-4 people and a maximum of 8 . During the first phase, the facilitator submits to the thinking community a story from that book. Those participants who wish to do so read part of the story as suggested by Pelletier and Renaud in their project (Pelletier; Renaud 2011: 138). A dilemma or a philosophical question is brought to light based on this reading. The participants' proposals are written down on a paperboard, as well as the questions that might be of interest.

The second phase will highlight the differences between the viewpoints. That demands not only that you listen, but that you participate in the discussion by expressing an argument for or against something. The main task of the facilitator is to allow the participants to clarify their different point of views, and to encourage critical thinking. Everyone in the group should be given a chance to speak. Here also, the various responses and arguments should be written on a second board which will be used to work with in the $2^{\text {nd }}$ session. As Gagnon (2011: 149) has written: “A question which is of interest collectively without having been pre-determined" should emerge during this second phase.

The third phase focuses primarily on questions raised by particulars. Any or all would like to discuss based on the notes taken and saved during the first session. The goal of this second session is to experience the deepening of a line of thought, to encourage effort and perseverance in the thought process without being afraid of tensions. Important ideas found in those discussions are written down.

The fourth phase during this session will allow us to reach a temporary conclusion based on those important ideas. We shall endeavour also to generalize one's attitude by distancing oneself from concrete examples in order to reach a form of abstraction or generalization.

The different concluding proposals made are written down in order to keep a trace of what has been developed. It will be possible to review the different boards which have been used to take notes.

"The reflective exercise expected by philosophical practices in PRC should help direct our interest to the principles, the foundations, the values or the concepts which are presupposed and called for in the treatment of a particular question,” specifies Gagnon (2011: 149). In that respect, a philosophically-oriented discussion is different from a group therapy which is much more focused on the resolution of personal problems shared by the members of the group. In the case of a philosophically-oriented discussion, beyond the reflective exercise, as claimed by Clot (2015: 221), "for instance, the feeling that you are sharing the same story is a resource which has proven to be successful in the fate of emotions conveyed by the body, when the affect reconverts passivity into activity.” It may well be that this activity of discussing from a tale or myth allows for such a process. In fact, according to Journet (2014), the myths keep on transforming themselves and one can make them speak the language of the day.

After a two-session module made out of four phases, we have asked the participants to evaluate the input of the module.

We then called 7 patients about a month later in order to get a second feedback and find out what it could tell us more, and to see if the patients consider that it has had an impact on their life. It is difficult to separate the patient's stay altogether from their participation in the workshop. However, we want to take note of the fact that all the people which we have contacted remember, and are able to relate that experience to an element of their relational or personal life.

Concerning the other 7 patients, we only called those two months later. In this case, there is a more distant 
memory that needs to be reactivated by indicating the title of the myth or the tale which was used for the discussion.

Data collection and analysis is made out of audio recordings of the discussions followed with qualitative analysis of their content. The recorded results are rather encouraging, even if is only an exploratory research.

\section{Results and analysis}

The experience of recovering is more and more acknowledged in helping people who are experiencing psychological distress. Provencher (2002) has been trying to articulate some theoretical perspectives. Based on the work of Perkins and Zimmerman (Perkins \& Zimmermann 1995; Zimmerman 1995) she suggests that four dimensions are implied inn recovery:

1. Redefining and expanding oneself

2. Relating with the temporal et noetic space

3. Being able to take action

4. Relating to others

These four dimensions could be used as a guide for developing empirical research.

Those elements can also be found in Huguelet (2013) who thinks that the process of recovery is found in hope and self-determination. He also observes four elements in that process which we are linking with those recognized by Provencher (2002):

1. Finding hope (Relating with the temporal and noetic space)

2. Redefining identity (Relating with redefining and expanding oneself)

3. Finding meaning in life (Relating to others and to temporal space)

4. Assuming active responsibility for recovery (Relating with being able to take action)

Excerpts from speeches or distinctive sentences from the evaluations made by patients have been put on a chart, using the four dimensions of recovery and their features according to Provencher (2002). This chart can be viewed by accessing the report online (Ansen Zeder 2015: 10).

As a first observation, Provencher's model can possibly be used to classify the discourse by taking into account the four dimensions of recovery.

Each of these patients can say something that relates to one of the dimensions of recovery. Experience mentions rather positive elements that could be associated with the process of recovery.
The perspective of recovery is not part of normalization but rather a valorisation of transformations oriented toward what is becoming, and the improvement of wellbeing and one person's quality of life.

We would like to emphasize that this experience about a philosophically-oriented discussion could highlight three tenets found in logotherapy:

1. Self-distancing and self-transcending, an expression of the freedom of the will, when we examine verbatim in the category redefining and expanding oneself,

2. Expressing the will to meaning which defines human motivation, when we examine verbatim in the category being able to take action,

3. Registering search for meaning involving affective and noetic aspects in expressions of hope, transcending fears and desires of the self, when we examine verbatim in the category relating with the temporal and noetic space, and relating to others.

Therefore we think that philosophically-oriented discussions may enhance the practice of logotherapy, for serving the purpose of spiritual care

In a small intermediary health care structure for people with mental distress, to better understand experiences of transformation and targeting interventions are objectives to address.

In palliative care, clinicians and researchers emphasize also the importance of hope for conveying meaning. In this context Philippin (2013:14) points out: "in daily clinical practice hoping to heal and getting ready for imminent death are looked upon together and not separately." Based on the work of Block (2000) Philippin (2013: 12) points out that the psychologist needs to examine the question of what is "normal" and what is pathological: "A differentiated diagnostic needs to be made between self-bereavement and pathological depression."

However, if we refer to Provencher (2002), this process of self-bereavement is also to be found in the presence mental distress, in the dimension of redefining and expanding oneself. Since the authors mention the importance of hope and spirituality, how can a psychologist or a psychotherapist integrate those two dimensions? Are any tools available to him? Could the practice of philosophical thinking communities become such a tool?

Contacting patients two months later has been more difficult. Since patient 11 and patient 14 could not be reached by phone, we merely lean on the written evaluation done after the second session. Patient 10 could be reached by phone. The telephone conversation with patient 12 was very limited. However, it was enough to evoke the allegory which has been used, and to indicate the 
location of their stay in order for the patients contacted to remember. In general, they asked to be reminded what they had written on the evaluation sheet. Concerning this group of patients, nobody has been able to participate to 2 or 3 modules. From our point of view, this has an impact on group dynamic. The relationship forged has been more limited. However, here also the recovery model of Provencher (2002) allows us to establish a classification of the discourse. This second chart can be accessed by reading the report online (Ansen Zeder 2015: 11).

Here also, the experience induces rather positive elements. Several questions can therefore be raised:

1. Could taking into account the spiritual dimension of people in mental health care be used as a therapeutic tool? Under which conditions?

2. Could the integration of the spiritual dimension be considered an ethical necessity in such care?

3. Could finally the philosophical thinking community or the philosophically-oriented discussion become «tools» serving the acknowledgment of the noetic or spiritual dimension in a care venue? Taking into account the perspective of search of meaning as defined in logotherapy?

For the first question, care literature insists on the idea that "healing is not only dependent on a therapeutic activity, but also on a process that brings us beyond what can be measured, mastered and known, but which has to be accounted for", as pointed out by Frick (2011: 6). To recover does not necessarily mean to heal, but knowing how to take into account one's vulnerability and to live by building one's own resources and being able to mobilize them. Menning (2015) promotes the view that this skill can be acquired. Huguelet (2013: 95-96) also points out: "that some imagination is needed to explore potential areas that could provide meaning. [...] to start with the values of the subject represents a technique sometimes even able to overcome blockages.” The dimension of secular spirituality and religion is actually part of those fields.

Therefore the question of integrating the spiritual dimension has been discussed for many years within the scientific and medical community. In view of providing holistic care it is not any longer possible to ignore this noetic or spiritual dimension of the person. Frankl (2006) has understood it well!

Furthermore, to focus only on psychiatric symptoms is not enough to work towards recovery. The resources available in patients are of great interest and to evaluate them can already be of therapeutic value according to BellierTeichmann (2015). Furthermore, if the issue of meaning "is but a part of the clinical approach centred on recovery", as pointed out by Huguelet (2013), it must be looked upon as a complement to other possible therapeutic actions, without forgetting the existential approach which includes the dimensions of self-determination, loneliness and the finitude of human beings.

The question of tools to address this dimension is not an easy one. The key issues of spiritual anamnesis as proposed by Frick (2005), with the help of SPIR, are interesting for addressing the topic and to give indications to the health workers / caregivers.

Could the model of spiritual needs STIV [French acronym for Sens (Meaning), Transcendance (Transcendence), Valeurs (Values) and Identité (Identity)] put into place in geriatrics by Monod, Rochat, Büla and Spencer (Monod et al. 2010) be adapted to patients suffering from mental distress? This model is interesting as an interdisciplinary work which includes the chaplain into the health care team, and also allows for a structured and systematic approach of evaluating spirituality as pointed out by Monod-Zorzi (2012).

Could the practice of the philosophical thinking community or the philosophically-oriented discussion enrich the set of tools used in introducing patients to hope and spirituality, yet respecting the plurality of their beliefs and cultural origins? This group practice would allow to integrating psychotherapists, health workers and chaplain into one interdisciplinary work group.

In conclusion, we believe that the philosophicallyoriented discussions could enrich the practice of logotherapy, especially narrative logotherapy, and serving the purpose of spiritual care and foster care thinking. Indeed, is the search for meaning not one of the bases of logotherapy which has proven to be efficient for mental disorders?

\section{References}

Ansen Zeder E (2015) Communauté de Recherche Philosophique (CRP) dans un lieu d'accueil intermédiaire pour des adultes en fragilité psychique temporaire. Haute Ecole pédagogique Fribourg (online). 02.11.2015 (Zitierdatum 02.11.2015), abrufbar unter http s://doc.rero.ch/record/257496.

Besson J (2014) Invited A vue d'esprit rts2.ch. (2014, February 10). Santé Mentale et spiritualité (online podcasted). 10.02.2014, (Zitierdatum 16.09.2015), abrufbar unter http://pages.rts.ch/ espace-2/programmes/a-vue-d-esprit/5561540-.html

Bellier-Teichmann T (2015) Vers un profil de compétences. Quelles ressources peut-on mobiliser pour améliorer son bien-être? Psychoscope Revue FSP 4:17-19.

Block S.D. (2000) Assesing and managing depression in the terminally ill patient. Annals of internal Medecine 132:209-218 
Cinq-Mars C (2005) Etude sur l'impact du programme „Prévention de la violence et philosophie pour enfants“ (online) 16.09.2013 (Zitierdatum 16.09.2015), abrufbar unter www.latraversee-pvphi e.com/ppt/recherche1.pptwww.latraversee-pvphie.com/ppt/re cherche1.ppt.

Clot Y (2015) Vygotski avec Spinoza, au-delà de Freud. Revue philosophique de la France et de l'étranger 140:205-224.

Dahlsgaard K, Peterson C, Seligmann ME (2005) Shared virtue. The convergence of valued human strengths across culture and history. Review of General Psychology 9:209-213.

Frankl V $(1996,2006)$ Découvrir un sens à sa vie avec la logothérapie. Montréal: Les éditions de l'homme.

Frick E (2005) Peut-on quantifier la spiritualité? (Online). 29.08.2011 (Zitierdatum 14.07.2015), abrufbar unter www.cath-vd.ch/IMG/p df/Peut_on_qantifier_la_spiritualite_E_Frick-2.pdf.

Frick E (2011) Se laisser guérir. Réflexion spirituelle et psychanalytique. Bruxelles: Lumen Vitae.

Gagnon M (2011) La pratique de la philosophie en communauté de recherche auprès de personnes en centre de jour. In: Sasseville M, Gagnon M (Hg.), La communauté de recherche philosophique. Applications et enjeux: Laval: PUL. 145-153.

Gaillard Wasser J (2013) Peut-on choisir son conditionnement? Presented at the 4 ème cycle de conférences Science et Foi, Université de Lausanne; 02.10.2013.

Hess A C (2013) L'encadrement aporétique en Philosophie pour Enfants et Adolescents. (Rapport final de recherche d'une intervention sur le terrain en 2012.). Fribourg: Haute Ecole pédagogique Fribourg.

Hess A C (2014) L'encadrement aporétique en philosophie pour enfants et adolescents (PPEA) ou comment faire progresser la pensée des enfants et des adolescents en mettant leur entendement dans l'embarras. Childhood \& Philosophy 10(19):55-86.

Huguelet $P$ (2013) Le rôle des valeurs et du sens de la vie dans le rétablissement des troubles mentaux sévères. Swiss Archives of Neurology and Psychiatry 3/164:90-98.

Journet N (2014) Les grands mythes: pourquoi ils nous parlent encore ? Revue Sciences Humaines Les Grands Dossiers 37:5-78.

Lipman M (1995). Caring as Thinking. Inquiry: Critical Thinking Across the Disciplines 15: 1-13.

Lipman M (2006) A l'école de pensée. Enseigner une pensée holistique. Bruxelles: De Boeck.

Loison Apter E (2010). Les effets psychothérapeutiques de l'activité philosophique à partir du dialogue philosophique en communauté de recherche selon Matthew Lipman. Travail de Master en Relation d'aide et Intervention Thérapeutique sous la direction de Dr. Galam E Professeur associé Université Paris Diderot et Sasseville M., Professeur agrégé, Faculté de philosophie, Université de Laval. (Not Published)

Loison Apter E (2011) Les effets psychothérapeutiques de l'activité philosophique à partir du dialogue philosophique en communauté de recherche selon Matthew Lipman. Diotime Revue Internationale de Didactique de La Philosophie. (online) 15.06.2013 (Zitierdatum 15.06.2013), abrufbar unter http://www.educ-re vues.fr/DIOTIME/Enregistrement.aspx?iddoc $=39476$.

Menning H (2015) Le système immunitaire psychique. Les coups durs sont nécessaires pour évoluer.Psycoscope Revue FSP 4:10-12.
Monod S, Rochat E, Büla C, Spencer B (2010) The Spiritual Needs Model : Spirituality Assessment in the Geriatric Hospital Setting. Journal of Religion, Spirituality and Aging 22:271.

Monod-Zorzi S (2012) Soins aux personnes âgées. Intégrer la spiritualité? Bruxelles: Lumen vitae.

Pelletier L, Renaud F (2011) Penser par et pour soi-même en alphabétisation. In: Gagnon M, Sasseville M (Hg.) La communauté de recherche philosophique. Applications et enjeux. Laval: PUL. 135-144.

Perkins DD, Zimmerman MA (1995) Empowerment theory, research, and application. American Journal of Community Psychology 23:569-579.

Pesseschkian N (2009) L'utilisation d'histoires orientales en psychothérapie positive. Le Marchand et le Perroquet. Paris: L'harmat$\tan$.

Peterman A et al. (2002) Measuring spiritual well-being in people with cancer: the functional assessment of chronic illness therapyspiritual well-being scale. Annals of Behavioral Medicine (FACITSp) 24:49-58.

Peterson C, Park N (2011) Forces de caractère et vertus leur classification et leur évaluation. In : Martin-Krumm C, Tarquinio C (Hg.) Traité de psychologie positive. Bruxelles: De Boeck. 233-248

Philippin Y (2013) Redonner du sens à la fin de la vie. Psychoscope Revue FSP 34/8-9:12-15.

Piquemal M (2003) Philofables. Paris: Albin Michel.

Provencher H L (2002) L'expérience du rétablissement : perspectives théoriques. Santé mentale au Québec 27: 35 (online) 15.06.2013 (Zitierdatum 10.07.2013), abrufbar unter https://doi.org/10.720 2/014538ar.

Remacle M, François A (2011) La souffrance : de la phénoménologie herméneutique à la clinique. Sciences Croisées 7 (online) 15.06.2013 (Zitierdatum 16.09.2013), abrufbar unter http://sci ences-croisees.com/N7-8/pro/REMACLE.pdf.

Ribalet J (2008) De l'intérêt des ateliers philosophiques pour la prévention de la souffrance psychique. Diotime Revue Internationale de Didactique de La Philosophie 37 (online) 15.06.2013 (Zitierdatum 16.09.2013), abrufbar unter http://www.educ-revues.fr/ DIOTIME/AffichageDocument.aspx?iddoc $=38937$.

Rivier E, Hongler T, Suter C (2008) La spiritualité en soins palliatifs. Guide Des Soins Palliatifs Du Médecin Vaudois 5 (online) 05.05.2013 (Zitierdatum 05.05.2013), abrufbar unter www.svme d.ch/wp-content/uploads/2011/08/GSP-5_2008_Spiritualité.p df.

Tozzi M (2010) Le mythe comme support à une réflexion philosophique avec les élèves | Philotozzi (online) 29.08.2011 (Zitierdatum 15.06.2013), abrufbar unter http://www.philotozzi.com/2010/0 4/le-mythe-comme-support-a-une-reflexion-philosophique-ave c-les-eleves.

Tozzi M (2012) Nouvelles pratiques philosophiques. Répondre à la demande sociale et scolaire de philosophie. Lyon: Chronique Sociale.

Zimmerman MA (1995) Psychological empowerment: Issues and illustrations. American Journal of Community Psychology 23:581-599. 